\title{
PARTISIPASI POLITIK PEREMPUAN DALAM PEMBANGUNAN ACEH PASCAKONFLIK
}

\author{
Cut Asmaul Husna \\ Fakultas Ilmu Sosial dan Politik, Universitas Teuku Umar \\ Email: acutbusu2@yahoo.com \\ Email: cutasmaulhusna@gmail.com
}

\begin{abstract}
Abstrack
After conflict aceh development much more developing and industrialized in various sectors, aceh start rise from bankruptcy economy, social and cultural, political, infrastructure. Resurrection aceh in development pascakonflik caused by participation of various parties and the in aceh, including the perempuan.studi aims to see and understand political participation daughters of development in aceh pascakonflik as learning to daerah-daerah in indonesia even negara-negara else in the world which still experience conflict or development problems in doing rekontruksi and rehabilitation after conflick.The theory of the research is theory political participation focusing on women involvement in the decision, planning, implementation, the use of the development and the evaluation aceh pascakonflik development. Studies show that women aceh have been involved active in the development, however the impact of participation in political sector is still very low against the construction of aceh.In the context of economic and political, women aceh still have a great opportunity struggling to get a reasonable rights should be equal treatment with the laki-laki in development aceh because undang-undang aceh give space all its citizens participate in development without except for .Because bias gender, where yardstick chance and ability often seen from the sexes put women position at a lower, besides the ability to improve the quality of women in an effort to their involvement through the political in aceh development.
\end{abstract}

Keywords: women, political participation aceh, development. 


\section{PENDAHULUAN}

Perempuan Sebagai Tiang Negara, apabila wanitanya baik maka negara akan baik dan apabila wanita rusak maka negarapun akan ikut rusak". Pepatah ini menunjukan bahwa wanita berperan penting dalam membina keutuhan dan kinerja sistem dalam suatu Negara, Bangsa dan Daerah termasuk untuk Aceh. Peran perempuan Aceh dalam pembangunan dan politik, banyak mengalami pasang surut seiring dengan situasi dan perkembangan keadaan. Pada masa lampau, suatu tonggak sejarah gemilang menjadi catatan penting dalam kehidupan berbangsa dan bernegara, bahwa perempuan Aceh mempunyai peran dan porsi yang cukup signifikan, sebagai penguasa Aceh yang dimulai dari masa pemerintahan Sri Ratu Safiatuddin Tajul Alam, Putri dari Iskandar Muda Johan Pahlawan Meukuta Alam (1641-1675), Sri Ratu Naqiatuddin Nurul Alam (1675-1678), Sri Ratu Zaqiatuddin Inayat Syah (1678-1688), Sri Ratu Kamalat Syah Zinatuddin (1688-1699). Ratu-ratu Aceh pada waktu itu memiliki kemampuan dalam pemerintahan dan bersinergi dengan ulama untuk membangun Aceh.

Masa berikutnya saat perempuan Aceh memberikan kontribusi mempertahankan Aceh dari jajahan Portugis dan Belanda. Banyak data sejarah menunjukkan bahwa kaum perempuan juga ikut bergabung dalan peperangan sebagai pejuang yang tangguh berdampingan dengan laki-laki. Dalam setiap event mereka memainkan peran yang sangat penting. Laksamana perempuan pertama yaitu Laksamana Keumalahayati mampu memimpin pasukan Inoeng Balee melawan Portugis, lalu Cut Nyak Dhien, Cut Meutia adalah nama-nama yang telah tercatat menjadi pahlawan nasional dalam mempertahankan negerinya. Sejarah membuktikan bagaimana perjuangan dan ketangguhan kaum perempuan Aceh dalam memimpin perang untuk mengusir para penjajah. Perempuan yang berani nyalinya memegang senjata tajam dan menghunusnya ketubuh para musuh. Mereka telah memberikan semangat dan inspirasi tersendiri sebagi pejuang dalam usaha mempertahankan kemerdekaan bangsa.

Pascakemerdekaan Republik Indonesia, gerakan perempuan muncul sesuai dengan perkembangan kondisi Aceh, saat konflik Aceh mulai terjadi dari DI/TII, perang Cumbok, Aceh Merdeka hingga masa Gerakan Aceh Merdeka, perempuan Aceh bergerak melalui organisasiorganisasi bentukan pemerintah atau ormas seperti PKK, Dharma Wanita, Dharma Pertiwi, Aisyiah, Muslimat NU, BKOW dan organisasi lainnya sama halnya di daerah lain di Indonesia. Tokoh-tokoh perempuan Aceh masa itu, penulis hanya mengenal nama Hj. Ummi Fatimah Cut Lampoh Saka yang sangat terkenal sebagai orator ulung dan pernah menjadi anggota DPRD Kabupaten Pidie selama dua periode serta memimpin Dayah Diniyah Fatimiyah dan Panti Asuhan Fatimiyah di Gampong Lampoh Saka, Kabupaten Pidie. Orator dan politisi perempuan ini pernah mengingatkan pemerintah Aceh agar memberdayakan ulama perempuan dalam pembangunan ke depan ${ }^{1}$. Setelah era itu kita mengenal nama Cut Cayarani Bitai sebagai politisi Golkar dan pernah menjabat deputi bidang Pendidikan, kesehatan dan Pemberdayaan Perempuan BRR Aceh tahun 2008.

Ketika reformasi bergulir tahun 1998, saat reformasi digulirkan gerakan perempuan Aceh sangat baik, sejumlah buffer aksi dan LSM Perempuan muncul, beberapa buffer Aksi dibentuk perempuan Aceh seperti Forum Komunikasi Mahasiswi Aceh (FKAMA), Solidaritas Mahasiswi Islam Peduli Aceh (SMIPA), Solidaritas Perempuan untuk Referendum Aceh (SPURA), Lampuan, Flower Aceh, Balai Syura dan banyak organisasi lainnya. Gerakan perempuan Aceh saat itu, tidak hanya berperan menumbangkan rezim Orde Baru, terlibat dalam investigasi kasus-kasus HAM di Aceh, pencabutan DOM, Konggres perempuan untuk penetukan sikap politik Aceh dan berkontribusi pada perundingan dan perdamaian Aceh, tetapi 
juga mengisi era Reformasi ini dengan sejumlah kerja-kerja kongkret yang berorientasi kemajuan untuk memperjuangkan hak-hak perempuan menuju kesetaraan dan keadilan.

Duek Pakat Inong Aceh (DPIA) pada 7 Agustus 1998 yang kelahirannya berangkat dari kongres besar yang didukung oleh organisasi perempuan berbasis massa yang merupakan perwakilan/representasi perempuan dari kabupaten/kota di Aceh dengan rekomendasi diantaranya diselesaikannya masalah perdamaian di Aceh dan mendorong pelibatan penuh perempuan dalam proses perdamaian Aceh. Selain itu, ada Inoeng Balee yang merupakan organisasi bentukan Gerakan Aceh Merdeka (GAM).

Penulis mengenal banyak tokoh perempuan melalui gerakan politik dan sosial kita mengenal Cut Nurasyikin, Naimah Hasan, Suraiya Kamaruzzaman, Khairani, Syarifah Rahmatillah, Sakdiah Marhaban, Raihan Diani, Arabiyani, Ainal Mardhiah, Maryati SH, M.Hum, Sri Wahyuni dan beberapa nama lainnya yang luput dari penulis dalam tulisan ini yang sering muncul namanya di media massa dengan berbagai peran-perannya. Penulis ikut bagian bersama mereka untuk ikut berkontribusi dalam mewujudkan Aceh yang bermartabat, tegaknya demokrasi dan perdamaian di Aceh.

Begitu pula dimasa awal-awal pembangunan Aceh di era pascaMOU Helsinky, gerakan perempuan Aceh muncul sebagai bagian dari mendukung perdamaian terlepas dari kepentingan politik tertentu, kaum perempuan di Aceh telah terlibat secara aktif dan positif dalam menggerakkan roda-roda pembangunan sebagaimana tercermin dalam berbagai bentuk perkumpulan atau gerakan sosial lainnya. Perempuan memainkan peranan yang sangat penting dalam proses pembangunan perdamaian di Aceh. Mereka aktif melaksanakan berbagai kegiatan dalam menunjang upaya pembangunan perdamaian. Kegiatan-kegiatan ini antara lain: kampanye penegakan hak-hak azasi manusia khususnya perempuan, advokasi, pemberdayaan ekonomi perempuan, dan penyaluran bantuan kemanusiaan dan kebutuhan pokok kepada masyarakat baik pada masa konflik maupun pada saat tsunami. Konflik juga telah mendorong banyak perempuan di Aceh untuk menjadi aktivis perdamaian dan tokoh masyarakat. Sebahagian aktivis perempuan di Aceh merupakan mahasiswa pada masa konflik dan sangat bersemangat dalam menyuarakan isu perdamaian dengan ala mahasiswa, seperti demonstrasi dan juga tuntutan referendum. Sementara aktivis yang sudah lebih senior lebih mengupayakan dengan cara pendampingan korban, advokasi dan dialog dengan berbagai pihak untuk mencari format tentang Aceh damai.

Semenjak damai menyentuh Serambi Mekah, moment ini seharusnya menjadi awal kebangkitan dari cengkraman kekuasaan militer yang telah masuk disegala aspek kehidupan bermasyarakat di Aceh sebelumnya saat konflik, perempuan Aceh bangkit disegala kehidupan dengan isu yang terus berkembang di kancah dunia, dimana peran dan fungsi perempuan di tengah-tengah masyarakat menjadi semakin terbuka lebar dengan adanya dukungan dari sejumlah undang-undang dan peraturan yang membuka peluang yang lebih besar untuk menunjukkan eksistensinya sebagai bagian dari warna negara yang mempunyai hak dan kewajiban yang sama dengan yang lain.

Namun, dalam negara yang menganut sistem nilai patriarkal, seperti Indonesia termasuk Aceh tentunya, kesempatan perempuan untuk menjadi politisi relatif terbatasi karena persepsi masyarakat mengenai pembagian peran antara laki-laki dan perempuan, yang cenderung bias kearah membatasi peran perempuan wanita pada urusan rumah tangga, pada akhirnya perempuan Aceh terjebak pada rendahnya partisipasi politik yang berpengaruh pada daya ungkit pencapaian indikator pembangunan yang komplek dalam berbagai sektor.

Berbeda dengan provinsi lain, begitu gencarnya perempuan-perempuan melakukan berbagai gerakan sosial dan politik, mereka tampil dalam masyarakat melakukan pemberdayaan dan mereka tampil menjadi walikota/bupati. Ketika berbagai taruhan tentang kemampuan perempuan untuk memimpin bangsa ini, di daerah lain inovasi-inovasi dan keberanian untuk membangun tantanan dan tata kelola pemerintahan lebih baik (good governance) justru datang 
dari perempuan meskipun dibaluti oleh tekanan-tekanan politik dan sosial. Lihat saja kemampuan Tris Rismaharini Walikota Surabaya dalam menutup lokalisasi dan membangun semrautan kota surabaya lebih baik dan walikota perempuan lainnya yang mengimplementasikan tatakelola pemerintahan yang baik yang berdampak pada lajunya pembangunan. Meskipun ada catatan suram juga dari politisi dan kepala daerah yang dari perempuan yang terlibat dalam lembaran hitam kasus korupsi.

Konflik sudah berakhir di Aceh yang ditandai dengan penantangan Nota Kesepahaman antara Pemerintah Republik Indonesia dan Gerakan Aceh Merdeka (Memorandum of Understanding Between The Government of Republic of Indonesia And The Free Aceh Movement Helsinki 15 Agustus 2005), Pemerintah Republik Indonesia dan Gerakan Aceh Merdeka menegaskan komitmennya untuk menyelesaikan konflik Aceh secara damai, menyeluruh, berkelanjutan dan bermartabat bagi semua, dan para pihak bertekad untuk menciptakan kondisi sehingga Pemerintaha Aceh dapat diwujudkan melalui suatu proses yang demokratis.

Salah satu hasil dari MoU Helsinky adalah adanya Undang-Undang Pemerintahan Aceh sebagai manifestasi untuk Aceh dalam mengelola provinsi dengan banyak kewenangan dan begitu juga dengan adanya Undang-Undang tentang Pemerintah Daerah sebagai bagian dari hak otonomi daerah yang memiliki kewenangan sangat besar dalam mengelola kabupaten/kota. Saatnya Aceh menuju perdamaian yang hakiki, melaksanakan pembangunan dalam berbagai sektor mewujudkan kesejahteraan masyarakat sehingga memerlukan keikutsertaan semua pihak termasuk perempuan. Maka, peranan perempuan sangat penting dan gerakan perempuan sangat mendukung untuk itu, terlebih lagi porsi perempuan terlibat dalam politik lebih besar serta adanya keamanan dan kenyamanan perempuan untuk lebih berani bertindak, berbuat dan menyatukan ide dan pikiran untuk terlibat dalam politik serta gerakan sosial lebih luas sehingga mampu menjadi jembatan untuk menerima aspirasi masyarakat. Harapannya gerakan perempuan harus mengembalikan kepercayaan diri dan kemampuan pada diri kaum perempuan untuk bisa menolong dirinya sendiri. Berdasarkan latar belakang tersebut maka penulis untuk mempelajari pelajari bagaimana partisipasi politik perempuan dalam pembangunan Aceh Paskakonflik, kontribusi perempuan dalam pembangunan Aceh baik dalam pengambilan keputusan, perencanaan, pengawasan dan pelaksanaan evaluasi serta bagaimana SDM perempuan Aceh dalam menggerakkan pembangunan Aceh?

\section{METODE PENELITIAN}

Penelitian ini bersifat kualitatif, berangkat dari ketertarikan penulis terhadap objek yang diamati. Penulis menggunakan data primer dan sekunder, dengan teknik pengumpulan data melalui studi pustaka dan diperkuat dengan pengamatan terjun langsung ke lapangan. Berbagai literasi atau media bacaan baik buku, majalah, dan surat kabar serta banyaknya media online baik jurnal, situs, maupun laporan hasil riset yang terkait dengan topik terkait dengan partisipasi politik perempuan di Aceh terhadap pembangunan di Aceh pascakonflik.

Selain itu untuk memperkuat kajian penulis dalam melakukan penelitian, penulis juga mengumpulkan data dengan tehnik meminta pendapat masyarakat melalui media sosial facebook mengenai pendapat mereka tentang gerakan dan peran perempuan Aceh dalam pembangunan pascakonflik. Ada lima (5) orang yang memberikan pendapat mereka tentang keterlibatan perempuan Aceh dalam pembangunan di Aceh. Lima orang yang memberikan komentar yaitu Win Fahrud, Lena Mardhiah, Raja Umar, Muchlis Ade Putra dan mantan aktivis Aceh Rahmad Djaelani (sesuai dengan nama facebook).

\section{HASIL PENELITIAN DAN PEMBAHASAN}

\section{Perempuan dalam pengambilan keputusan melalui parlemen.}

Pascakonflik di Aceh, minat perempuan terjun ke wilayah politik terjadi peningkatan yang sangat dratis sebagai akibat dari ketentuan kebijakan kuota $30 \%$ perempuan di wilayah 
politik. Selain itu kampanye dan sosialisasi yang dilakukan oleh penggiat perempuan yang konsen pada isu keterwakilan dalam politik, pemerintah, organisasi-organisasi kemasyarakatan dan yang tidak kalah pentingnya adalah dukungan positif media massa dengan berbagai liputan dalam perjuangan mengenai perlunya peningkatan keterwakilan perempuan dalam politik tidak terlalu mengalami hambatan dan tantangan karena telah memberikan kenyamanan bagi perempuan dalam memperjuangkan hak politiknya.

Secara kuantitatif jumlah anggota Dewan Perwakilan Rakyat Aceh (DPRA) dari perempuan periode 2014-2019 mengalami penambahan dari periode sebelumnya sebanyak empat (4) orang menjadi 12 orang yang mewarnai proses demokrasi dan memberikan pengaruh besar dalam mengambil keputusan melalui parlemen. Berdasarkan data anggota DPR Aceh sebanyak 81 Orang, perempuan yang duduk di kursi DPRA 12 orang anggota DPR Aceh perempuan periode 2014-2019 yaitu; (1) Darwati A. Gani dari Partai Nasional Aceh, dalam Pemerintahan Aceh perempuan ini tak asing lagi, istri mantan gubernur Irwandi Yusuf. Selama lima tahun menjadi first lady di Aceh menjadi popular dan dengan mudah memenangkan Pileg 2014; (2) Nurlelawati dari Partai Golongan Karya, untuk kedua dipercayakan masyarakat Pidie dan Pidie Jaya sebagai perwakilan mereka di parlemen; (3) Kartini Ibrahim dari Partai Gerindra sebagai pendatang baru untuk parlemen Aceh; (4) Ummi Kalsum dari Partai Aceh; (5) FauziahH.M.Daud dari Partai Golongan Karya kembali menjadi partai yang mengantarkan politisi perempuan ke parlemen; (6) Ismaniar dari Partai Amanat Nasional asal Gayo; (7) Nuraini Maida dari Partai Golongan Karya; (8) Fatimah dari Partai NasDem, sebagai partai baru NasDem ternyata juga mempunyai kader perempuan yang berkualitas; (9) Yuniar dari Partai Golongan Karya yang termasuk politisi senior, 15 tahun menjadi anggota legislatif; (10) Liswani dari Partai Amanat Nasional, ini periode kedua duduk di parlemen Aceh; (11). Siti Nahziah dari Partai Aceh sebagai kader baru perempuan dari Partai Aceh yang berhasil menguasai parlemen Aceh; (12) Mariati MR dari Partai Aceh dengan lulusan S3 mampu meniti jalan mulus untuk mengamankan kursi untuk menduduki parlemen Aceh.

Selain pertambahan perempuan di parlemen, pascakonflik tercatat baru satu-satunya Perempuan yang menjadi Kepala Daerah yaitu Illiza Saa'dudin Jamal menjadi Walikota Banda Aceh yang dilantik setelah meninggalnya Mawardy Nurdin, yang mengembangkan tugas sebagai kepala daerah yang memiliki kewenangan dan tanggungjawab yang melekat sebagai politisi dan tanggungjawab sosial. Dengan adanya kepala daerah perempuan, maka dipastikan pengaruhnya sangat besar dalam berbagai sektor pembangunan.

Dari data tersebut menunjukkan bahwa partisipasi perempuan dalam pengambilan keputusan melalui parlemen jauh lebih baik daripada masa periode sebelumnya. Dengan berbagai latar belakang dan kemampuan yang dimiliki perempuan Aceh menduduki parlemen dan kepala pemerintahan dapat memberikan energi baru dalam memperjuangkan aspirasi masyarakat, membela hak-hak perempuan, memastikan perencanaan yang berpihak secara adil dan merata bagi masyarakat Aceh, mampu mendorong perubahan dalam melaksanakan pembangunan dengan tatakelola pemerintahan yang baik, melakukan pengawasan yang konsisten sebagai representative dari rakyat, sehingga memberikan dampak langsung dalam pembangunan Aceh dalam berbagai sektor, terjadinya perubahan yang signifikan dalam pembangunan baik dalam aspek ekonomi maupun aspek non ekonomi yang mencakup bidang hukum, sosial budaya dan politik.

Meskipun anggota DPRA dan satu kepala daerah yang perempuan sangat minim, belum memenuhi quota sebagaimana undang-undang yang menegaskan perempuan harus memenuhi 30 persen di parlemen, namun tidak melemahkan eksisitensi mereka dalam bekerja yang efektif dan berpera strategis dalam menggerakan pembangunan di Aceh.

\section{Partisipasi Politik Perempuan dalam Perencanaan Pembangunan}


Praktek baik yang telah dilakukan Kota Banda Aceh dan beberapa Kabupaten/kota lain di Aceh layak dijadikan referensi dan contoh bagi daerah lainnya dalam perencanaan pembangunan. Dalam upaya meningkatkan partisipasi perempuan untuk memberikan ruang publik dan politik, Kota Banda Aceh melaksanakan Musyawarah Perempuan untuk Perencanaan Pembangunan (Musrena).

Gagasan tentang perlunya Musrena dilatarbelakangi oleh keprihatinan akan rendahnya partisipasi kaum perempuan di Kota Banda Aceh dalam proses perencanaan pembangunan, sementara komposisi jumlah penduduk perempuan dan laki-laki di Kota Banda Aceh relatif berimbang.

Selain itu, ditemui adanya beberapa penyimpangan dari aturan normatif dan bersifat tidak ramah terhadap keterlibatan perempuan. Dalam proses perencanaan didapatkan beberapa situasi sebagai berikut: 1) Peserta yang terlibat dalam proses perencanaan, dari Musrenbang di tingkat desa sampai dengan Musrenbang di tingkat kota, kebanyakan adalah perangkat pemerintah atau tokoh masyarakat. Kelompok masyarakat awam jarang sekali terlibat, apalagi kelompok perempuan. Kalaupun ada kelompok perempuan yang terlibat, hanya dari kelompok PKK atau isteri dari aparat pemerintah. 2) Minimnya keterlibatan perempuan mengakibatkan usulan yang dihasilkan kurang berpihak kepada perempuan. Usulan pembangunan fisik dan infrastruktur masih menjadi primadona, tetapi usulan berupa perbaikan gizi, peningkatan kualitas hidup anak melalui pemberian makanan tambahan,posyandu dan usulan serupa lainnya, hampir tidak pernah muncul. 3) Waktu dan tahapan yang harus dilalui oleh masyarakat dalam proses ini sangat panjang dan melelahkan, selain itu tidak ada kepastian bahwa usulan masyarakat akan diakomodir.4) Minimnya keterwakilan perempuan di DPRD juga sangat menentukan keluaran/hasil dari negosiasi dalam proses perencanaan. 5) Proses perencanaan, seperti halnya proses lain di daur penganggaran, tidak memperhatikan penerima manfaat dari anggaran yang direncanakan/disusun.

Namun belum semua kabupaten di Aceh melakukan Musrena sebagai proses pelibatan masyarakat dalam perencanaa, sehingga ada pihak yang belum merasa adanya partisipasi politik perempuan sebagai sebuah gerakan dalam pembangunan. Dalam pengamatan penulis, keikutsertaan perempuan dalam perencanaan melalui kegiatan musrenbang baik ditingkat gampong, Kecamatan, Kabupaten bahkan provinsi masih sangat rendah dan terbatas. Keberadaan perempuan masih terabaikan dalam proses perencanaan terutama dalam musyawarah tingkat gampong, bentuk partisipasi politik dengan ikut bergabung dalam musyawarah gampong yang dominannya laki-laki sering dianggap tak biasa bagi perempuan. Padahal, UU Desa sudah mem beri ruang partisipasi bagi perempuan, tapi implementasinya masih menemui sejumlah masalah. Begitu pula dengan keluarnya permendes yang mengatur partisipasi kelompok perempuan. Ketidakterlibatan perempuan dalam forum-forum partisipasi warga di gampong diduga juga terkait dengan masalah kapasitas aparat gampongyang tidak paham tata kelola Gampong. Aparat Gampong banyak yang tidak paham bagaimana melibatkan perempuan dalam forum-forum di gampong dalam perencanaan.

Dalam hal partisipasi politik perempuan dalam perencanaan, ada tigal hal menurut penulis mengapa perempuan masih rendah partisipasinya dalam perencanaan di Aceh. Pertama, Karakter Aceh yang khas menganut system parthiakal, seakan-akan membatasi gerak perempuan untuk lebih jauh dalam politik, meskipun sejarah masa lampau tidak demikian. Kedua, pola interaksi antarwarga masyarakat perempuan yang tidak intensif dan tidak memiliki kemampuan untuk membangun relasi dengan pimpinan daerah sehingga mempengaruhi peluang partisipasi politik perempuan, ketiga, tingkat kemampuan SDM perempuan dalam mengorganisir kelompok perempuan sendiri dan mendorong kelompoknya untuk sama-sama mengadvokasi agar dapat terlibat dalam proses perencanaan yang merupan entry point dalm pelaksanaan pembangunan, sehingga wajar saja kemudian ada pihak yang mengkalim bahwa 
perempuan belum fokus dalam memperjuangkan hak-haknya dan belum memiliki kemampauan dalam mengorganisir dirinya sebagai subjek dan objek dalam pembangunan.

Berikut beberapa komentar beberapa teman penulis melalui media facebook setelah penulis menulis status untuk meminta pendapat facebooker tentang gerakan perempuan dan partisispasi perempuan dalam pembangunan ; "Gerakan perempuan di Aceh sudah mati, kebanyakan gerakan perempuan pencari makan dengan mengatasnakan perempuan, hanya sedikit sekali perempuan yang memperjuangkan hak-hak perempuan, komentar Win Fahrud melalui facebook. Pendapat lain dari Lena Mardhiah "Untuk Tahun 2017 belum nampak sosok perempuan yang bisa memimpin Aceh ke depan, bukan saya tidak mendukung perempuan, tapi sosok perempuan Aceh saat ini menjadi pemimpin Aceh sudah habis stok. Justru media mengenal Mak Nong sebagai perempuan hebat "Perempuan hebat kalau menurut saya adalah Mak Nong dan sejumlah perempuan tangguh lainnya di kawasan Tutut Kecamatan Sungai Mas Aceh Barat, aktifitas sehari-hari mereka mendulang emas dengan cara tradisional dan ramah lingkungan "sebagaimana ditulis Raja Umar melalui media sosial. Facebooker lain Muchlis Ade Putra juga memberikan komentar "Saya sepakat dikatakan Pak Umar, Mak Nonglah yang terkenal menurut versi media, tapi mana tau versi lain ada yang lebih hebat selain Mak Nong, yang intinya wanita Aceh semua pada dasarnya hebat-hebat dan cerdas untuk menentukan sikap dalam perjuangan, namun belum maksimal. Sementara kritikan terhadap gerakan perempuan Aceh datang dari mantan aktivis Aceh Rahmad Djaelani yang menyampaikan komentarnya melalui media sosial "Gerakan perempuan di Aceh itu Dongeng, yang ada kelompok-kelompok perempuan yang cari makan berkedokkan gerakan perempuan”.

Karena itu dalam perencanaan pembangunan, perempuan harus mengubah formatnya untuk mencapai hasil yang lebih baik, lebih adil dan memiliki peran yang tidak hanya cukup menunggu tanpa meningkatkan keaktifan dan strategi perjuangan.

\section{Partisipasi Politik Perempuan dalam Pengawasan dan evaluasi Pembangunan}

Dalam penyusunan kebijakan perempuan dan perencanaan pembangunan, perempuan terlibat cukup bagus. Sayangnya, penulis belum mendapatkan data pengkaderisasi perempuanperempuan tangguh lainnya dan menjadikan penyeimbang atau sebagai Check and Balance dalam menjalankan roda pemerintahan. Pelbagai kebijakan yang telah disahkan di Provinsi Aceh kurang mendapatkan perhatian dan kritikan serta pengawasan dari kaum perempuan yang merupakan penduduk yang lebih banyak.

Aceh seperti kehilangan tokoh perempuan dan tidak ada kaderisasi yang memiliki ketangguhan untuk menyuarakan aspirasi sebagai gerakan bersama dari pelbagai pemangku kepentingan teroganisir yang menjadi sumber ilmu pengetahuan dan mampu mengerakan perempuan lain, menyatukan visi untuk mendorong kebijakan -kebijakan Pemerintah Aceh yang pro rakyat dan melakukan pengawasan yang teroganisir dengan dengan berkolaborasi dengan anggota parlemen perempuan, sehingga belum menjadi sebuah kekuatan bersama dalam melakukan kontrol dalam pembangunan.

Aktivis-aktivis Aceh masa lalu dan sekarang sepertinya larut dengan romantisme pekerjaan mereka atau kesibukan mereka dengan pekerjaannya atau hanya sekedar bertanggungjawab terhadap rutinitasnya sebagai ibu, istri dan pekerja, dengan sudah mulai pudar terhadap sensitivitas untuk kegiatan sosial, budaya, pendidikan dan politik secara luas terjun ke masyarakat.

Kiritikan tentang masih rendahnya partisipasi perempuan Aceh dalam perencanaan dan pengawasan saat ini seharusnya menjadi catatan penting bagi kaum perempuan yang harus digarisbawahi, ketika masih banyak pekerjaan rumah dengan berbagai isu perempuan, anak, bayi, masyarakat rentan, kelompok terdiskriminasi dan marjinal, maka kehadiran perempuan dalam gerakan nyata sangat dibutuhkan, bukan hanya bergerak secara indivial, kelompok dan parsial tapi mampu mendorong kebijakan 
yang lebih baik. Ide-ide gerakan perempuan pun tidak hanya mewarnai beragam aturan dan kebijakan, tetapi juga mendorong tumbuh dan berkembangnya organisasi-organisasi gerakan perempuan dalam kelompok civil society.

Partisipasi politik dalam hal pengawasan, perempuan sangat diharapkan partisipasinya dalam upaya meningkatkan control masyarakat terhadap implementasi kebijakan dan pelaksanaan pembangunan, dimana pelaksanaan kebijakan dan penyelenggaraan pembangunan sering sekali terjadi pengabaian hak atau bahkan penyimpangan dari azas-azas dan prinsip pembagunan bahkan bertolak belakang dengan perencanaan. Disinilah diperlukan partisipasi semua pihak untuk mendorong akuntabilitas dan transparansi dalam pelaksanaan pembangunan untuk memastikan pembangunan efektif dan efisien serta berbasil hasil atau output dengan memperhatikan perubahan struktural, memperhatikan pembangunan dan pertumbuhan sebagai proses keseluruhan, memperhatikan perubahan marjinal, mementingkan pada pertumbuhan dan menunjukan hubungan asosiatif.

\section{Tantangan Partisipasi Politik Perempuan Dalam Pembangunan Aceh}

Sejarah Aceh telah mencatat bahwa perempuan Aceh secara tangguh dapat memimpin Negara, memimpin di medan perang, terlibat dalam perundingan dan perdamaian serta gerakan sosial lainnya yang mampu mendobrak hegemoni kekuasaan dari lelaki dan bahkan mampu bersinergi dengan organisasi yang dipimpin para lelaki, meskipun tantangan dan hambatan lain masih tetap ada.

Perempuan Aceh yang memahami Islam juga memahami kedudukan, fungsi dan perannya perempuan, meskipun selalu mendapat tempat dan mengerti fungsinya sebagai ibu rumah tangga yang selalu harus di dapur atau mengurusi masalah rumah tangga, namun fungsi ini tidak menjadikan kelemahan posisi bagi perempuan untuk bergerak, justru bagaimana kemudian memaknakan fungsinya yang merupakan bagian dari masyarakat.

Dalam konteks ekonomi maupun politik, kaum perempuan Aceh masih harus berjuang untuk mendapatkan haknya yang wajar agar mendapatkan perlakuan yang sama dengan kaum laki-laki. Karena bias gender, dimana tolak ukur kesempatan dan kemampuan sering dilihat dari faktor jenis kelamin dengan menempatkan posisi perempuan pada posisi yang lebih rendah, masih sering kita jumpai dalam kehidupan sehari-hari di Aceh.

Tantangan lain dari gerakan perempuan di tingkat internal adalah belum kuatnya gerakan yang berbasis kesukarelaan diantara anggota gerakan, sehingga memiliki ketergantungan pada sumber pendanaan. Ketika pendanaan bergantung dari pihak lain, maka ketika pihak lain tidak membantu, para aktor gerakan banyak yang keluar dari organisasi gerakan dan berpindah kepada lembaga-lembaga yang menjamin dari aspek ekonomi. Hal ini bukan hanya terjadi di Aceh tapi juga Indonesia umumnya.

Media sosial sudah mulai adanya wacana yang pada dasarnya menggugat kembali peran dan fungsi perempuan di Aceh dalam setiap gerakan kelompok/individu dari golongan perempuan. Di tingkatan Nasionalpun Wacana tersebut tidak hanya menyangkut keinginan untuk mereposisi dan meredifinisikan kembali eksistensi kaum perempuan, tetapi mencakup pula adanya keinginan yang kuat untuk meningkatkan citra dan kualitas kaum perempuan di Indonesia. Hal ini didasarkan pada suatu kenyataan bahwa kaum perempuan di Aceh, masih banyak mengalami hambatan-hambatan struktural maupun non struktural, sehingga mereka belum dapat berperan secara maksimal baik dalam konteks kehidupan rumah tangga maupun sebagai individu manusia yang mempunyai keinginan-keinginan logis, untuk berperan lebih aktif di masyarakat.

Selain itu, Perempuan-perempuan dulu belum mampu melahirkan dan menguatkan kuatnya kader-kader baru yang dapat melanjutkan gerakan perempuan ke depan, sehingga belum terjadi penyebaran pengetahuan dan keahlian kepada generasi berikutnya di dalam anggota gerakan. Gerakan Politik perempuan pun cenderung terbagi ke dalam pelbagai faksi karena perbedaan pandangan dan strategi gerakan, sehingga kurang terjadi aksi, refleksi dan 
aksi bersama dalam menghadapi tantangan yang dapat melemahkan perjuangan perempuan untuk tujuan yang hendak dicapai. Organisasi-organisasi gerakan perempuan cenderung sibuk dengan pelaksanaan programnya masing-masing, sehingga kurang terjadi interaksi antara anggota gerakan.

\section{Komitmen Pemerintah Aceh}

Pascakonflik dan Era Otonomi Daerah seharusnya telah memberikan peluang yang lebih besar bagi kaum perempuan untuk berkiprah dan mengambil peran yang signifikan dalam pembangunan. Roh otonomi daerah pada hakekatnya merupakan sebuah pemberdayaan masyarakat lokal dalam membangun daerah, maupun negaranya bagi seluruh komponen warga Negara, termasuk bagi kaum perempuannya.

Keberadaan UUPA tentang Pemerintahan Aceh, seharusnya mendorong pemerintahan Aceh dapat melakukan inovasi dan kreatifitas kebijakan sesuai dengan sistusi dan kebutuhan masyarakat Aceh pascakonflik dan merawat perdamaian. Dalam konteks pemberdayaan perempuan, pemerintah seharusnya dapat memanfaatkan peluang ini untuk memberikan perhatian yang lebih baik terhadap eksistensi serta memaksimalkan peran kaum perempuan sebagai mitra dalam pembangunan. Gerakan perempuanpun seharusnya dapat mengarah pada memberikan dukungan kepada Pemerintah daerah meng-identifikasi permasalahan-permasalah yang dihadapi serta membuat skala prioritas strategis dalam menopang daya dukung pembangunan Aceh .

\section{Kualitas Sumber Daya Manusia (SDM) Perempuan Aceh}

Perlukah kita meragukan kemampuan sumber daya manusia perempuan Aceh? Jawabannya adalah data. Data menunjukan bahwa Aceh telah banyak memberikan beasiswa kepada perempuan-perempuan Aceh pascakonflik untuk mengambil pendidikan yang lebih tinggi baik dalam negeri maupun luar negeri. Namun dimana mereka pascalulus dari pendidikan tinggi tersebut? Apa kontribusi terhadap pembangunan di Aceh. Aceh tidak kekurangan sumber daya manusia perempuan dalam pengetahuan, perempuan Aceh semakin berkurang dari rentan tuna aksara. Tapi justru dalam memanfaatkan SDM nya perempuan Aceh cenderung memilih aman dan minim risiko, maka pilihan kerja menjadi Pegawai Negeri Sipil (PNS) lebih diminati ketimbang melakukan pemberdayaan masyarakat secara swadaya atau bergerak untuk terlibat dalam politik.

Pemanfaatan SDM untuk terlibat dalam politik hanya sedikit, keinginan untuk terlibat dipartai masih didasari untuk mengisi kekosongan untuk menjalankan kebijakan afirmatif merupakan bagian dari prinsip keadilan dalam demokrasi yang diimplementasikan melalui pemenuhan pencalonan minimal 30\% perempuan sebagai anggota legislatif. Penulis berharap adanya kesadaran secara luas menjadi bagian penerima aspirasi atau jembatan masyarakat untuk membantu memperjuangkan hak-hak mereka melalui parlemen, sehingga partisipasi perempuan di parlemen memiliki makna, arti, manfaat dan perannya sangat penting.

\section{Apa yang harus dilakukan kedepan ?}

Penulis memiliki harapan besar bahwa perempuan Aceh masih harus bangkit, bergerak dengan realitas sosial yang terjadi di Aceh saat ini. Perempuan Aceh harus mampu bersaing secara profesional, memiliki pengetahuan dan pemahaman yang sama dengan laki-laki dalam menguasai politik, ekonomi, sosial dan budaya di Aceh. Kontribusi dan partisipasi tidak cukup dengan menonton dan menyetujui dengan apapun yang terjadi di Aceh dalam keadaan ekonomi masyarakat yang belum banyak bergerak, pelayanan publik masih kacau, tatakelola pemerintah yang baik masih setengah hati, pengangguran makin meningkat, mutu pendidikan yang masih sangat rendah serta Indeks Pembangunan Manusia masih dibawah rata-rata Nasional.

Kelompok Perempuan Aceh harus mendorong bidang pemberdayaan perempuan, partai politik untuk memperkuat sinergitas dengan organisasi masyarakat, aktivis masyarakat sipil, dan 
komunitas/kelompok perempuan hingga tingkat akar rumput, mendorong partai politik untuk mencalonkan perempuan yang memiliki potensi kapabilitas dan jaringan akar rumput di wilayah basis kekuatannya, mendorong organisasi perempuan untuk dapat melakukan kaderisasi perempuan yang mampu mengisi pembangunan Aceh dan mendorong pesantren, dayah dan lembaga pendidikan islam untuk melahirkan ulama-ulama perempuan Aceh dan mubalighah Aceh, mendorong pemerintah Aceh untuk memberikan ruang dan gerak bagi professional perempuan Aceh, mendorong parlemen Aceh untuk percaya pada perempuan untuk melakukan pemberdayaan politik dan memberikan ruang suara di parlemen, mendorong organisasi perempuan untuk melakukan pemberdayaan dan pendidikan sosial, budaya, ekonomi bagi perempuan dan memiliki ruang pekerjaan sosial dan pembangunan moral sesuai dengan cita-cita pembangunan Aceh pascakonflik. Buktikan bahwa gerakan perempuan Aceh belum "Mati Suri”.

Ada 12 bidang kritis yang rentan sebagaimana hasil Deklarasi Beijing Platform for Action yang menjadi pekerjaan rumah yang harus diselesaikan sebagai berikut : Perempuan dan kemiskinan, Pendidikan dan pelatihan untuk Perempuan, kesehatan, Kekerasan terhadap perempuan, konflik bersenjata, ekonomi, Perempuan dalam kekuasaan dan pengambilan keputusan, mekanisme institusi untuk kemanusiaan perempuan, Hak Asasi Perempuan, Perempuan dan Media, Perempuan dan Lingkunga, Gadis Remaja.

Tidak ada perempuan yang terlibat, maka tidak ada demokrasi terwujud, maka sudah seharusnya Organisasi-organisasi gerakan perempuan turut membentuk sistem demokrasi, mengisinya dengan kerja-kerja nyata seperti menangani masalah-masalah: kekerasan terhadap perempuan dan anak, upaya pencegahan dan pemulihannya serta bantuan hukum dan psikologis bagi korban, pemberdayaan perempuan dalam bidang politik, ekonomi, akses terhadap informasi dan sumberdaya kehidupan dan akses terhadap keadilan hukum, Penanganan terhadap kasus-kasus kekerasan perempuan TKI semakin tinggi, Penanganan terhadap kasuskasus perdagangan perempuan (trafiking), Perjuangan untuk partisipasi perempuan dalam pengambilan keputusan di semua tingkatan pemerintahan, konflik sosial, bencana Alam, kemiskinan, tingginya kematian ibu dan bayi dan berbagai persoalan lainnya.

Sebagai bagian dari menjalankan syariat, seharusnya perempuan saling memberikan dukungan, melepaskan keegoan kelompok dan kepentingan, bersinergi dalam membangun Aceh, sebagaimana Allah berfirman dalam Al-Qur'an yang berbunyi "Al-Quran mengingatkan, "Janganlah kamu iri hati terhadap keistimewaan yang dianugerahkan Allah terhadap sebagian kamu atas sebagian yang lain. Laki-laki mempunyai hak atas apa yang diusahakannya dan perempuan juga mempunyai hak atas apa yang diusahakannya" (QS. An-Nisa': 32)

Lima tahun ke depan bahkan seratus tahun ke depan adalah saat Perempuan Aceh menguatkan dan mengartikulasikan kesadarannya dalam berpolitik, pemberdayaan ekonomi, membangun komunikasi dan saling berkoordinasi yang menjadi langkah strategis untuk terus menjaga keberlangsungan kehidupan bernegara.

\section{SIMPULAN}

Keterlibatan dan keterwakilan perempuan dalam dunia politik dan kebijakan publik merupakan suatu keharusan, sebab akses, kontrol, dan partisipasi politik perempuan dalam berbagai tingkatan pembuatan dan pengambilan keputusan merupakan hak asasi manusia. Tidak dapat dipungkiri perempuan secara demografis boleh dikastakan seimbang dengan laki-laki, namun secara politis mereka menempati posisi minoritas (Edriana Noerdin dari Women Research Institute tentang Demokratisasi dan Otonomi Daerah dimana Posisi Perempuan?)

Kalaulah boleh penulis mengutip apa kata Soekarno dalam bukunya Sarinah ; "bahwa soal wanita adalah soal masyarakat. Sayang sekali masalah wanita itu belum pernah dipelajari sungguh-sungguh oleh pergerakan kita. Kita tidak dapat menyusun negara dan menyusun masyarakat jika kita tidak mengerti soal wanita." Demikian penting soal wanita ini menjadi bahan bagi penyusunan masyarakat dan negara, sehingga pemahaman atas persoalan perempuan 
menjadi salah satu pijakan dalam membangun gerakan perempuan untuk mengantarkan pembangunan Aceh mewujudkan kesejahteraan, keadilan bagi rakyat Aceh.

Kesejahteraan sesungguhnya bertumpu pada kesejahteraan perempuan dan anak. Pengukuran terhadap tingkat kesejahteraan, bukaan sekadar jumlah pendapatan daerah tapi lebih mendasar lagi adalah soal kesejahteraan hidup yang meliputi kesehatan dan pendidikan. Angka kematian ibu dan anak (AKI), akses terhadap pendidikan yang murah dan berkualitas, angka tunaaksara, angka harapan hidup, akses terhadap pelayanan kesehatan, dan akses terhadap air bersih merupakan segelintir contoh indikator kesejahteraan dan indek pembangunan yang sesungguhnya sangat dekat dengan perempuan.

Kesimpulan inilah yang mendorong kenapa partisipasi politik perempuan harus ditingkatkan, sebagai alasan tercapainya tujuan pembangunan di Aceh baik untuk meningkatkan indeks pembangunan manusia, tercapainya MDGs menuju kemerdekaan yang sesungguhnya.

\section{REFENRENSI}

Adrana Venny. 2010. Memberantas Kemiskinan Dari Parlemen, Manual MDGs Untuk Anggota Parlemen di Pusat dan Daerah, Jakarta: Kemitraan

Bolgherini Silvia, 2010. "Participation" dalam Mauro Calise and Theodore J. Lowi, Hyperpolitics: An Interactive Dictionary of Political Science Concept Chicago: The University of Chicago

Fasli Djalal dan Dedi Supriadi. 2001. Reformasi pendidikan dalam kontek otonomi daerah. Jogyakarta: Adicita.

Joni Lovenduski. 2016. Politik Berparas Perempuan. Yogyakarta: Kanisius

Kalyanamitra. 2011. Menelisik Partisipasi Perempuan Dalam Musrenbang: Paper Kajian Kebijakan-Kebijakan Terkait, Jakarta.

Suharno. 2004. Diktat Kuliah Sosiologi Politik. Yogyakarta

Samuel P. Huntington dan Joan Nelson. 1990. Partisipasi Politik di Negara Berkembang. Rineka Cipta: Jakarta.

Tilaar, HAR. 2000. "Pengembangan Sumber Daya Manusia" dalam Globalisasi: Misi, Visi, dan Program Aksi Pendidikan dan Pelatihan Menuju 2020, Jakarta: Gramedia

Download:https://www.ajnn.net/news/daftar-anggota-dpr-aceh-periode2014-2019/index.html

Forum Tokoh Perempuan Aceh Bertekad Majukan Kaum Perempuan, RRI.co.id, 15 May 2015 